\title{
ANALYSIS OF NOVEL CURVE MICROSTRIPLINE ARRAY ANTENNA DESIGN IN X BAND FREQUENCY FOR SATELLITE COMMUNICATION
}

\section{Putu Artawan}

Ganesha University of Education, Singaraja, Bali, Indonesia

Email: artawan.putu@undiksha.ac.id

\begin{tabular}{|c|c|}
\hline FO & RACT \\
\hline $\begin{array}{l}\text { Received: } \\
\text { January, 26th } \\
2022 \\
\text { Revised: } \\
\text { February, } 17^{\text {th }} \\
2022 \\
\text { Approved: } \\
\text { February, } 18^{\text {th }} \\
2022\end{array}$ & $\begin{array}{l}\text { The design of a novel curve microstripline } 2 \times 2 \text { array } \\
\text { antenna is presented in this research. In this design, } \\
\text { antenna work in } X \text { Band frequency. The total size of } \\
\text { antenna is } 40 \mathrm{~mm} \times 40 \mathrm{~mm} \text {. The result indicates that the } \\
\text { antenna characteristics parametric showed by Voltage } \\
\text { Standing Wave Ratio (VSWR } 2 \text { ) of the proposed antenna is } \\
1.06 \text { (in simulated); } 1.29 \text { (in measured) and } 1.20 \text { (in numeric } \\
\text { analyzed), bandwidth is } 260.0 \mathrm{MHz} \text { (in simulated) and } 310.0 \\
\mathrm{MHz} \text { (in measured) and reflection coefficient is } 0.03 \text { (in } \\
\text { simulated) and } 0.17 \text { (in measured) and return loss is - } \\
29.43 \mathrm{~d} B \text { (in simulated) and -27.12dB (in measured) } \\
\text { respectively. The antenna has achieved a stable radiation } \\
\text { performance with a maximum gain of } 6.67 \mathrm{~dB} \text { (in simulated) } \\
\text { and 5.53dB (in mesured). Novel curve microstripline } 2 \times 2 \\
\text { array antenna with } 50 \text { Ohm impedance and easy } \\
\text { integration are making this model suitable for X-Band } \\
\text { frequency (8GHz-12GHz) satellite communication } \\
\text { applications. Details of the proposed antenna design and } \\
\text { results are presented and discussed. }\end{array}$ \\
\hline KEY & $\begin{array}{lcc}2 \times 2 & \text { Array; } & \text { Microstripline } \\
\text { Communication } & \end{array}$ \\
\hline c) (†) & $\begin{array}{l}\text { This work is licensed under a Creative Co } \\
\text { Attribution-ShareAlike } 4.0 \text { International }\end{array}$ \\
\hline
\end{tabular}




\section{INTRODUCTION}

To design and analyze the shape and size of the antenna required special knowledge regarding the electromagnetic field theory. Electromagnetic fields generated depend on the distance of the source access and terrain. The further course of electromagnetic fields produced less meaning in the spreading process electromagnetic waves from the transmitter to the receiver experiencing attenuation (weakening) signals. Therefore, the required antenna design with specific dimensions that have a high gain value and high directivity with return loss is very small. $[1,2,10,11]$. Various studies have been conducted on microstrip antenna type $[1,2,8,10,11,12,13,14,16]$, among which is to perform a wide variety of designs and shapes microstrip antenna, by giving the slot [18] and patch microstrip antenna and adding to the number of the array [17]. Use of the slot will be able to increase the bandwidth [15], the smaller the width of the slots will be even greater bandwidth while increasing the number of arrays will increase the directivity and the gain of the antenna [3,4]. The array of Antenna [17,19] is used to direct radiated power toward a desired angular sector. The number, geometrical arrangement, and relative amplitudes and phases of the array element depend on the angular pattern that must be achieved. One type of antenna that will be designed to have the characteristics in question are novel curved microstripline array antennas design. This antenna is an antenna type Microstrip with the characteristics of a thin cross-section, the mass that is lightweight, easy to make, can be easily integrated with Microwave Integrated Circuits (MICs) and can be made to multifrequency [5,6,7,9]. In this paper Novel curved microstripline array antenna design is propose to develope in X-Band frequency for many satellite communications transmisions. The proposed Novel curved microstripline array antenna is afford to operate in X-Band frequency in range $8 \mathrm{GHz}-12 \mathrm{GHz}$. The target of Novel curved microstripline array antenna is in $10.0 \mathrm{GHz}$ center frequency, reflection coefficient or return loss $\left(S_{11}\right.$ parameter) less than $-10 \mathrm{~dB}$, Voltage Standing Wave Ratio (VSWR) less than 2, input impedance close to $50 \Omega$, and gain more than $4 \mathrm{~dB}$ in linear polarization, respectively. Can be seen in Table 1 .

To design and analyze the shape and size of the antenna required special knowledge regarding the electromagnetic field theory. Electromagnetic fields generated depend on the distance of the source access and terrain. The further course of electromagnetic fields produced less meaning in the spreading process electromagnetic waves from the transmitter to the receiver experiencing attenuation (weakening) signals. Therefore, the required antenna design with specific dimensions that have a high gain value and high directivity with return loss is very small. $[1,2,10,11]$. Various studies have been conducted on microstrip antenna type $[1,2,8,10,11,12,13,14,16]$, among which is to perform a wide variety of designs and shapes microstrip antenna, by giving the slot [18] and patch microstrip antenna and adding to the number of the array [17]. Use of the slot will be able to increase the bandwidth [15], the smaller the width of the slots will be even greater bandwidth while increasing the number of arrays will increase the directivity and the gain of the antenna [3,4]. The array of Antenna [17,19] is used to direct radiated power toward a desired angular sector. The number, geometrical arrangement, and relative amplitudes and phases of the array element depend on the angular pattern that must be achieved. One type of antenna that will be designed to have the characteristics in question are novel curved microstripline array antennas design. This antenna is an antenna type Microstrip with the characteristics of a thin cross-section, the mass that is lightweight, easy to make, can be easily integrated with Microwave Integrated Circuits (MICs) and can be made to multifrequency [5,6,7,9]. In this paper Novel curved microstripline array antenna design is propose to develope in X-Band frequency for many 
satellite communications transmisions. The proposed Novel curved microstripline array antenna is afford to operate in X-Band frequency in range $8 \mathrm{GHz}-12 \mathrm{GHz}$. The target of Novel curved microstripline array antenna is in $10.0 \mathrm{GHz}$ center frequency, reflection coefficient or return loss $\left(S_{11}\right.$ parameter) less than $-10 \mathrm{~dB}$, Voltage Standing Wave Ratio (VSWR) less than 2, input impedance close to $50 \Omega$, and gain more than $4 \mathrm{~dB}$ in linear polarization, respectively. Can be seen in Table 1.

Table 1. Target of the antenna parameter.

\begin{tabular}{|c|c|}
\hline Parameters & Specification \\
\hline Center Frequency & $10.0 \mathrm{GHz}$ \\
\hline Input Impedance & Close to $50 \Omega$ \\
\hline $\mathrm{S}_{11}$ (Return Loss) & $<-10 \mathrm{~dB}$ \\
\hline VSWR & $<2$ \\
\hline Gain & $>4 \mathrm{~dB}$ \\
\hline Polarization & Linear (Vertical) \\
\hline
\end{tabular}

\section{Antenna geometry and design}

\section{RESEARCH METHOD}

The parameters of the Novel Curved Microstripline Array Antenna Design consist of the following table. (Table.2):

Table 2. Dimension Parameter of the Novel Curved Microstripline Array

Antenna Design.

\begin{tabular}{lll}
\hline Parameters & Dimension & \multicolumn{1}{c}{ Description } \\
\hline $\mathrm{Wg}$ & 100 & Width \\
$\mathrm{T}$ & 0.035 & Thick \\
$\mathrm{Lg}$ & 50 & Length \\
$\mathrm{H}$ & $1.6(+18 \mathrm{~mm})$ & High \\
$\mathrm{l}_{1}$ & $30 \mathrm{~mm}$ & Length of feeding stripline \\
$\mathrm{l}_{2}=\mathrm{l}_{3}$ & $15 \mathrm{~mm}$ & Length of curve stripline \\
$\mathrm{w}_{1}=\mathrm{w}_{2}$ & $1 \mathrm{~mm}$ & Width of stripline \\
$\mathrm{w}_{3}$ & $2 \mathrm{~mm}$ & Width of curve stripline \\
$\theta$ & $30^{\circ}$ & Gradient in curve line \\
\hline
\end{tabular}

The Curved Microstripline Array Antenna Dimension can be seen in Figure 1:

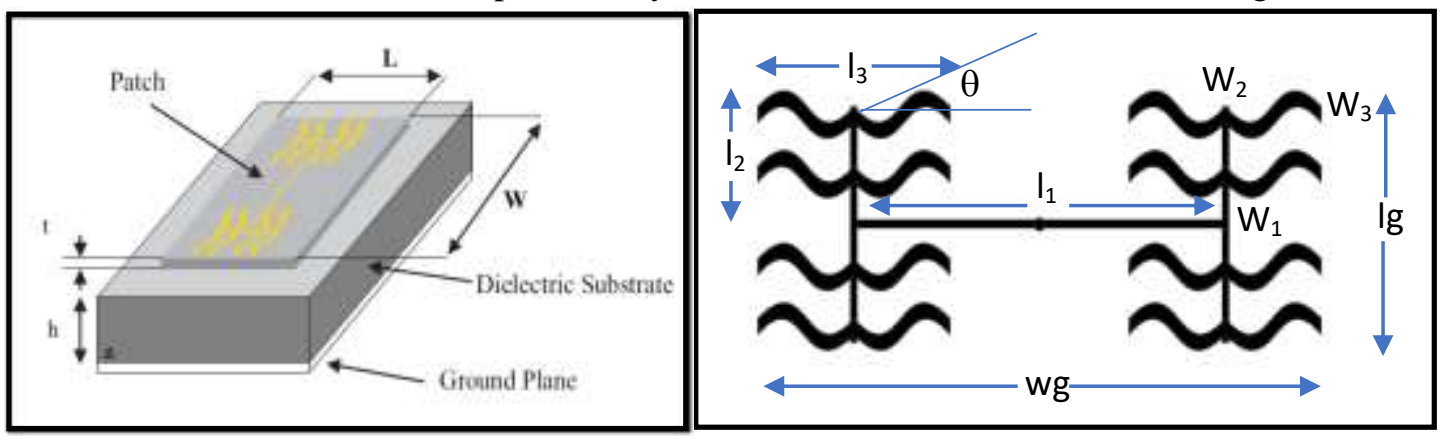

Figure 1. Curved Microstripline Array Antenna Dimension

The result of fabrication using $\mathrm{FR}_{4}$ substrate can be seen in the following figure (Figure 2): 


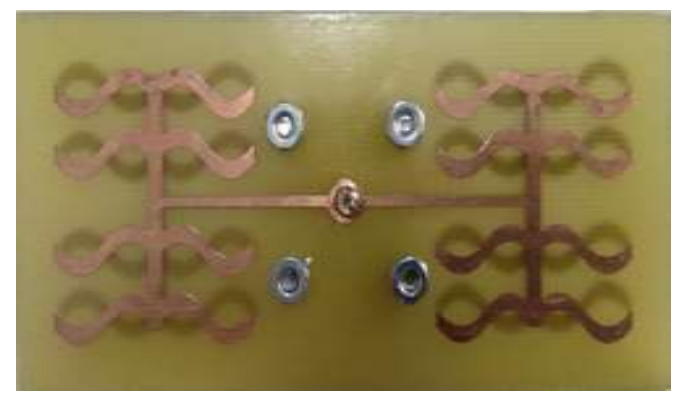

(a)

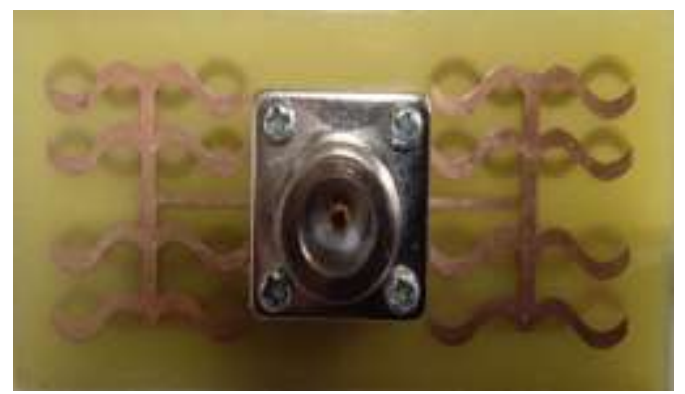

(b)

Figure 2. The fabricated prototype Curved Microstripline Array Antenna. (a) Top View (b) Back View

The simulations was created by using CST software. The result of simulation is presented in figure 3 .

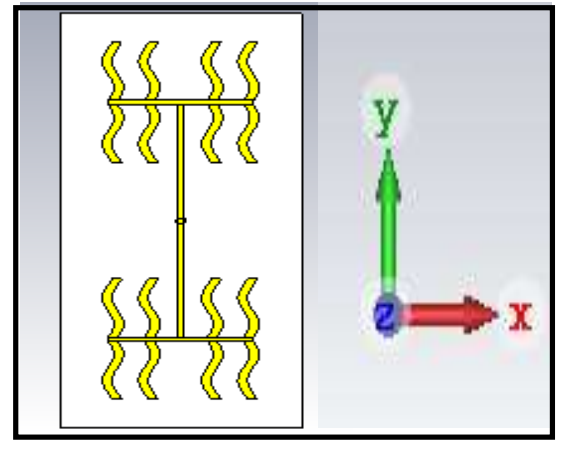

(a)

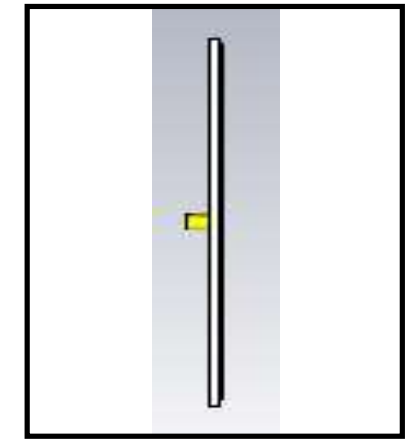

(b)

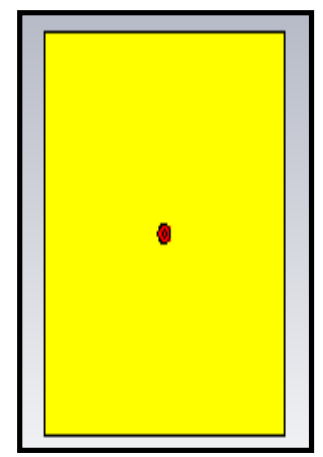

(c)

Figure 3. Simulation result Curved Microstripline Array Antenna.

a) Top View (b) Side View (c) Bottom View

The following figure (Figure.4) is Measuring Antenna at Laboratory.

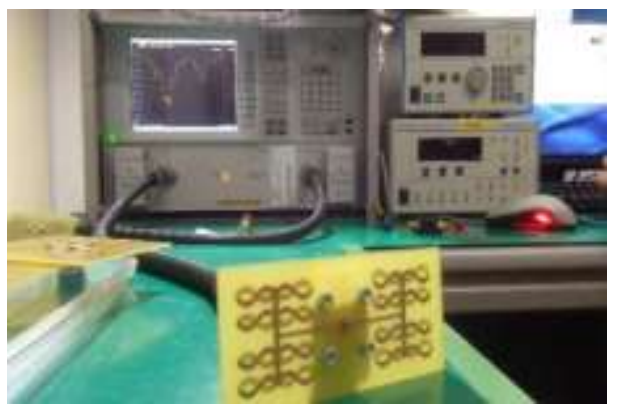

(a)

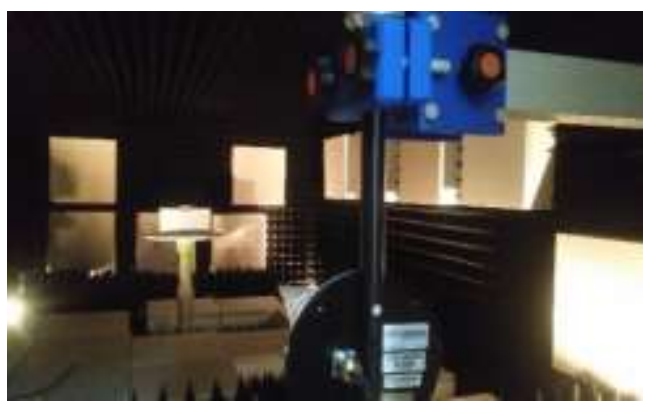

(b)

Figure 4. Measuring Process at Laboratory. 


\section{RESULT AND DISCUSSION}

In simulation Curved Microstripline Array Antenna work in $9.89 \mathrm{GHz}$ frequency with bandwidth range aproximately $260.0 \mathrm{MHz}(9.72 \mathrm{GHz}-9.98 \mathrm{GHz})$. The simulation result shown the antenna works well within the design frequency range. This indicate that the novel curved microstripline array antenna giving the good effect in bandwidth and antenna performance that can be apllied in communication especially in X-Band frequency range. The simulation shown in $S_{11}$ parameter is reflection coefficient 0.03 , Voltage Standing Wave Ratio (VSWR) 1.06, return loss $-29.43 \mathrm{~dB}$ and $6.67 \mathrm{~dB}$ in Gain. In measurement Curved Microstripline Array Antenna work in $9.84 \mathrm{GHz}$ frequency with bandwidth range aproximately $310.0 \mathrm{MHz}(9.66 \mathrm{GHz}-9.97 \mathrm{GHz})$, reflection coefficient 0.17 , Voltage Standing Wave Ratio (VSWR) 1.29 , return loss $-27.12 \mathrm{~dB}$ and $5.53 \mathrm{~dB}$ in Gain. The results of measuring and simulation can be described in the following figure (Fig. 5):

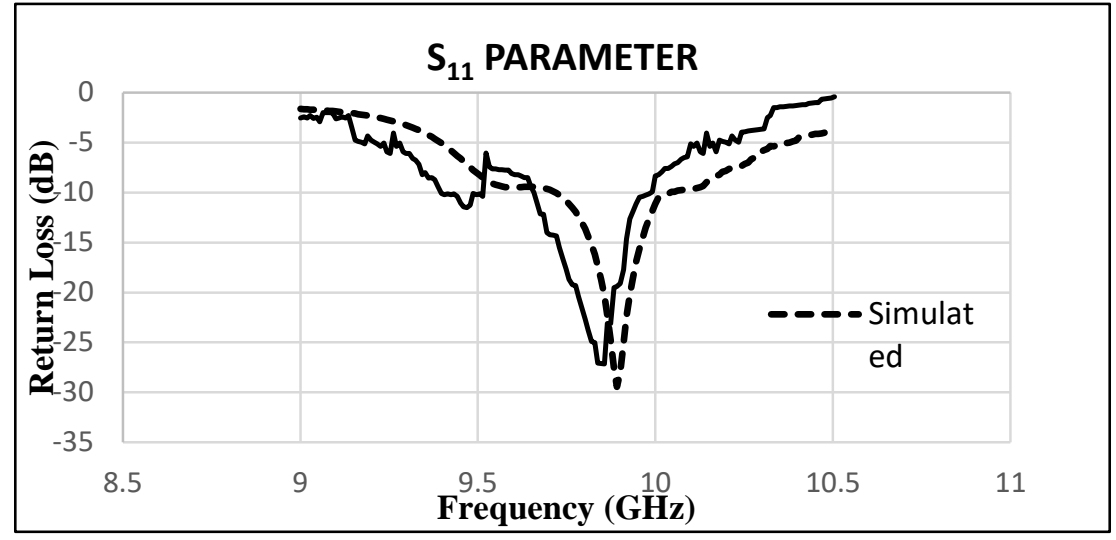

a) $\mathrm{S}_{11}$ Parameter.

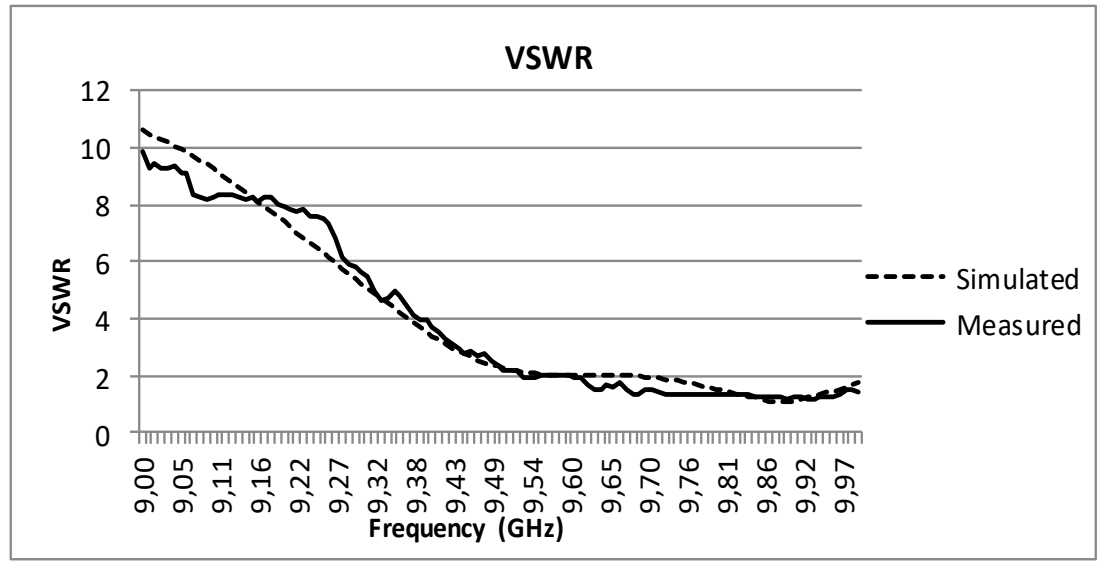




\section{Putu Artawan}

b). VSWR.

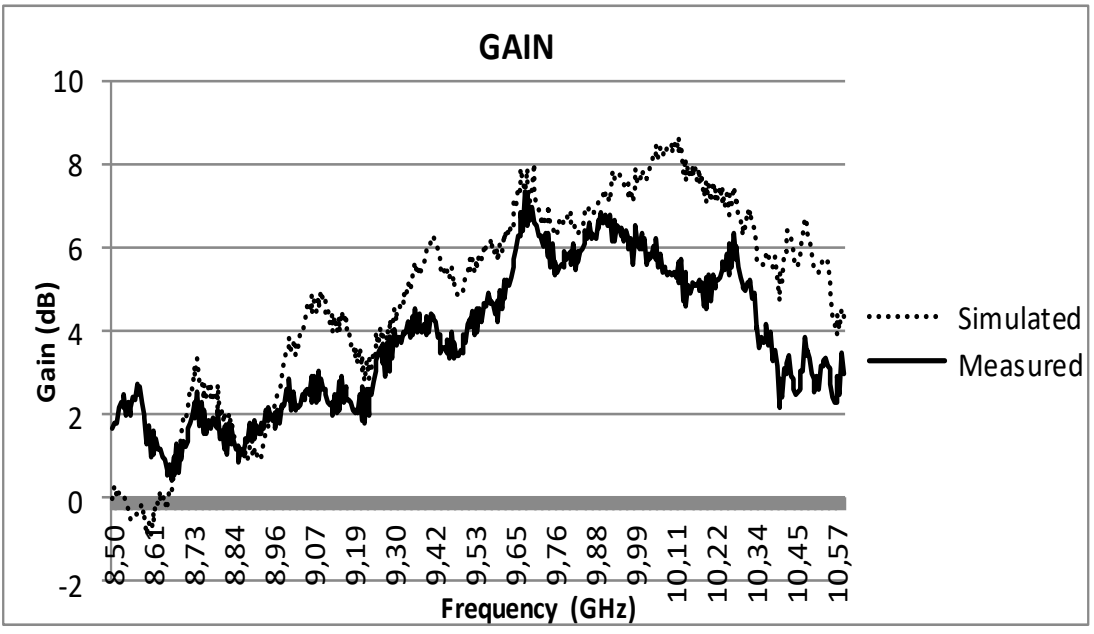

c). Gain

Figure 5. The result of Novel Circular Microstrip Patch Antenna.

The polarization and radiation pattern in curved microstripline array antenna is linear polarization and omnidirectional radiation pattern. The performance in terms of polarization in Curved Microstripline Array Antenna presented in Figure 6.

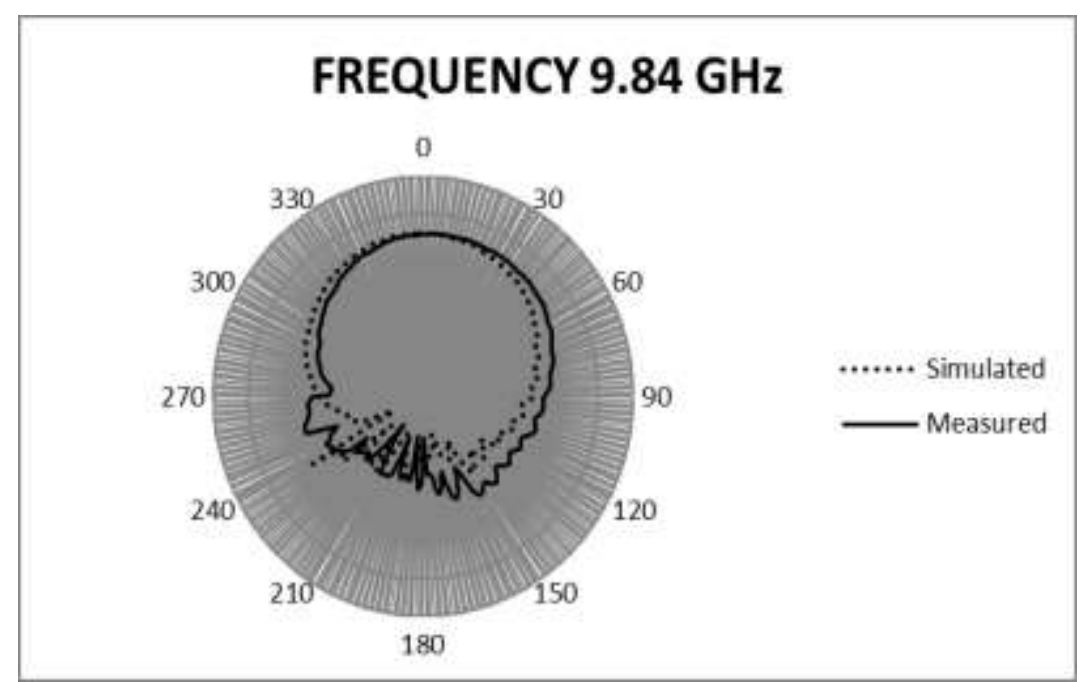

Figure 6. The Polarization of the Curved Microstripline Array Antenna

A maximum gain in simulation is $6.67 \mathrm{~dB}$ and in measurement is $5.53 \mathrm{~dB}$. That results to indicate that the Curved Microstripline Array Antenna gain is still acceptable for the X-Band antenna frequency. 


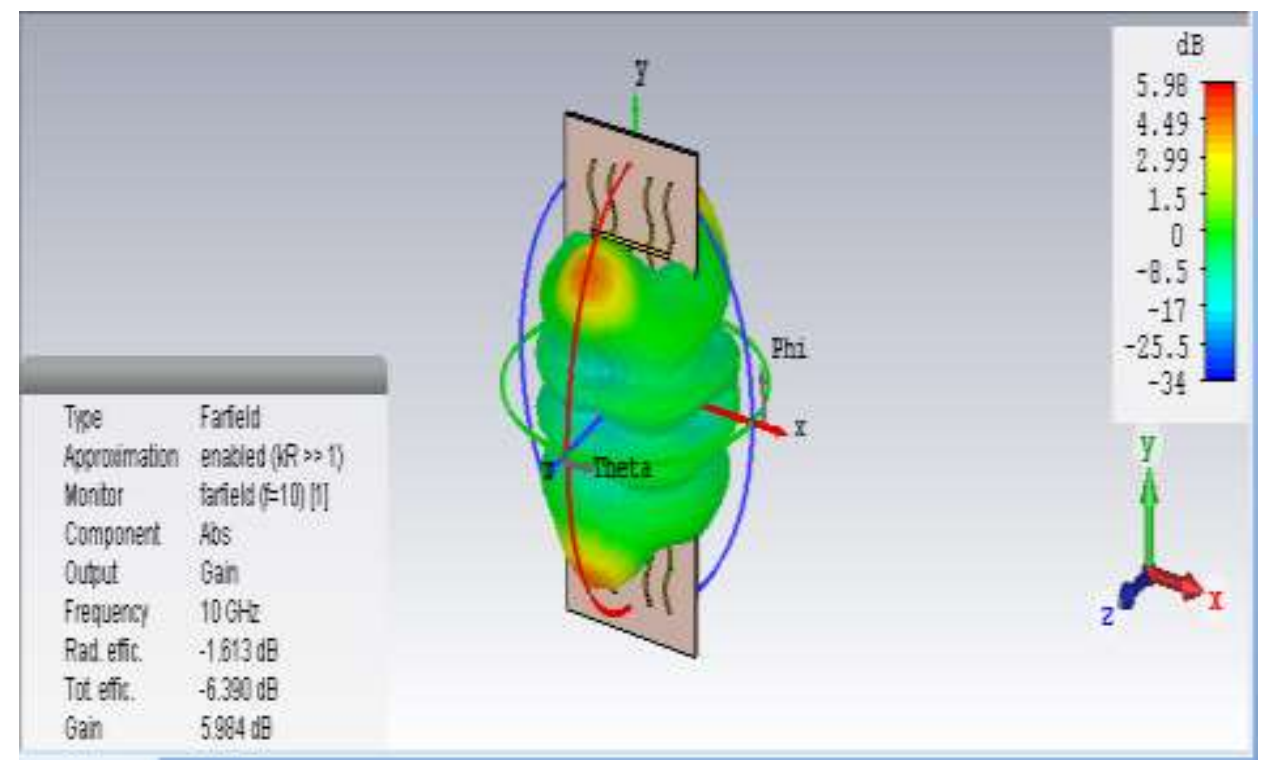

\section{Figure 7. 3D Far Field Polarization Pattern of the Curve Microstripline 2x2 Array Antenna.}

In general, the proposed antenna is designed to operate at X-Band and it can be observed from return loss and gain in antenna design that this antenna is suitable for being used in satellite communication. It can be easily observed from the radiation pattern that the designed antenna produces linear vertical polarization radiation pattern. There are some significant advantages if a patch antenna has a stable and symmetrical in radiation pattern. One of the major advantages is that during construction of an antenna, the radiation pattern would be more stable across the operating bandwidth.

\section{CONCLUSION}

The following table (Table.3) is summarizing the comparison between numeric analyzed, simulated and measured.

Table. 3. The result of comparison between numeric analyzed, simulated and measured.

\begin{tabular}{ccccc}
\hline Parameters & fc $(\mathbf{G H z})$ & RL $(\mathbf{d B})$ & VSWR & $\Gamma$ \\
\hline Numeric Analyzed & 10.00 & -20.92 & 1.20 & 0.09 \\
Simulated & 9.89 & -29.43 & 1.06 & 0.03 \\
Measured & 9.84 & -27.12 & 1.29 & 0.17 \\
\hline
\end{tabular}

These results indicate that the novel curved microstripline array antenna designed has the characteristics of antenna parameters that can be applied in X-Band frequency communications. In the next research, from this design will be develope to antenna design in Curved Microstripline Array Antenna with the circular polarization. 


\section{REFERENCES}

[1] Artawan. Fabrikasi dan Karakterisasi Antena Mikrostrip Tapered Patch Untuk Aplikasi Antena Panel Pada Frekuensi 2,4GHz. Tesis Magister, Jurusan Fisika, Fakultas Matematika dan Ilmu Pengetahuan Alam, Institut Teknologi Sepuluh Nopember (ITS), Surabaya, (2011).

[2] Artawan, Hadi Pramono, Yono. Perancangan Antena Panel Mikrostrip Horn Array $2 x 2$ Untuk Komunikasi Wi-Fi Pada Frekuensi 2,4GHz. Prosiding Simposium Fisika Nasional (SFN), ITS, Surabaya, (2010).

[3] Balanis, C.A. "Antena Theory Analysis and Design". Second Edition, John Wiley and Sons, New York, (1997).

[4] Edward, Terry. "Foundation for Microstrip Circuit Design". Knaresborough England, (1991).

[5] Shafai. "Microstrip Antena Design Handbook". Profesor University Of Manitoba, Wimmipeg, Canada, (2001).

[6] Kraus, John, D. "Electromagnetics". Third Edition, McGraw-Hill, New York, (1984).

[7] Ohri, V, Amin, O, Gebremariam, H Dubois, B. "Microwave Mikrostrip Horn Antena Design and Test System”. San Jose State University, (2003).

[8] Masduki, K. Desain, Fabrikasi dan Karakterisasi Antena Mikrostrip Biquad dengan CPW (Coplanar Waveguide) pada Frekuensi Kerja 2,4GHz. Program Magister Bidang Keahlian Optoelektronika Jurusan Fisika, FMIPA-ITS: Surabaya. (2009).

[9] Hund, E. "Microwave Communications, Component and Circuit”. McGraw Hill, New York, (1989).

[10] Hadi Pramono, Yono. Karakterisasi Antena Mikrostip Patch $3 \mathrm{GHz}$ Secara Simulasi FDTD (Finite Difference Time Domain) Dan Eksperimen. Jurnal Fisika. Institut Teknologi Sepuluh Nopember. Surabaya, (2005).

[11] Hadi Pramono,Yono. Prototipe Antenna Bi-Mikrostrip Tapered Patch dengan Dua Arah Pola Radiasi Dan Satu Feeding Monopole Beroperasi Pada Freq.2,4GHz. Prosiding T.Informatika, UPN. Yogyakarta, (2009).

[12] Hidayah, Ifa. Desain dan Fabrikasi Antena Bi-Mikrostrip Tapered Patch dengan Dua Arah Radiasi dan Satu Feeding Monopole Untuk Komunikasi Wi-fi. Tesis Magister. Institut Tekologi Sepuluh Nopember. Surabaya, (2009).

[13] Naqiah, Hawaun. Fabrikasi dan Karakterisasi Antena Mikrostrip Loopline untuk Komunikasi Wireless Local Area Network (WLAN). Program Magister Bidang Keahlian Optoelektronika Jurusan Fisika FMIPA-ITS: Surabaya, (2009).

[14] Risfaula, Erna. Antena Mikrostrip Panel Berisi 5 Larik Dipole dengan Feedline Koaksial Waveguide untuk Komunikasi 2,4GHz. Program Keahlian Optoelektronika Jurusan fisika FMIPA-ITS: Surabaya, (2011).

[15] Haider Raad, "An UWB Antenna Array for Flexible IoT Wireless System," Progress In Electromagnetics Research, (2018). Vol. 162, 109-121.

[16] Kumar Dwivedi M, Srivastava Pragati. "Microstrip Patch Array Antenna for XBand Application". Antenna Test and Measurement Society (ATMS India-16), 0103 (Feb, 2016). 
[17] Ranjani M.N, Sivakumar B. "Analysis of Linearly and Circularly Polarized Microstrip Patch Antenna Array". International Journal Of Electrical, Electronics And Data Communication, (July. 2016): ISSN: 2320-2084, Volume4, Issue-7.

[18] Reddy Vishnu Vardhana C, Rana Rahul. "Design Of Linearly Polarized Rectangular Microstrip Patch Antenna Using IE3D/PSO". Thesis. Bachelor Technology in Electronics and Communication Engineering. Department of Electronics and Communication Engineering. National Institute of Technology. Rourkela. (2009).

[19] Madhav, B.T.P, Sai Gupta, G, Rahul, M, Lahari Krishna, Sameera, M. "Linearly Polarized Microstrip Planar Filtenna for $\mathrm{X}$ and $\mathrm{Ku}$ Band Communication System". Indian Journal of Science and Technology, Vol. 9 (38), (October. 2016): DOI:10.17485/ijst/2016/v9i38/97115. 